Vol. 1 No. 1, Feb 2021, hlm. 89 - 94

DOI: https://doi.org/10.33330/.v1i1.1051

Available online at https://jurnal.stmikroyal.ac.id/index.php/jutsi

\title{
METODE ANALYTICAL HIERARCHY PROCESS (AHP) DALAM PENILAIAN KOMPETENSI SOFT SKILL PEGAWAI KANTOR BALAI DESA AMBALUTU
}

\author{
Dewi Safitri ${ }^{1}$, Dewi Anggraeni ${ }^{2 *}$, Suparmadi ${ }^{3}$ \\ ${ }^{1}$ Mahasiswa Prodi Sistem Informasi, STMIK Royal \\ ${ }^{2}$ Prodi Sistem Informasi, STMIK Royal \\ ${ }^{3}$ Prodi Manajemen Informatika, STMIK Royal \\ *email: anggraeni1987@gmail.com
}

\begin{abstract}
Employees are a highly needed human resource. In order to achieve the desired goals, the agency conducts performance assessments on the soft skill competencies of its employees. Employee performance appraise based on communication, honesty, cooperation, and personal skills. Analytical hierarchy proces (AHP) method, pairwise comparison assesment to get priority value. In this srudy, the result show the rasio of 0.07 which means that the assesment is consistent because it is less than 0.1 , so that the percetage of the calculation is $40 \%$, honesty $34 \%$, cooperation $17 \%$, and personal $10 \%$. The result of this study indicate that the AHP method can be used a method for assesing the soft skills competence of employeesof the ambalutu village office.
\end{abstract}

Keywords: Analytical Hierarchy Process (AHP), Soft Skill, Village hall Office

Abstrak: Pegawai merupakan sumber daya manusia yang sangat dibutuhkan. Demi mencapai tujuan yang diinginkan maka instansi melakukan penilaian kinerja terhadap kompetensi soft skill pegawainya. Penilaian kinerja pegawai berdasarkan kemampuan Komunikasi, Kejujuran, kerja Sama, dan Personal. Metode Analytical Hierarchy Process (AHP), penilaian perbandingan berpasangan untuk mendapatkan nilai prioritas. Pada penelitian ini menunjukkan hasil rasio 0.07 yang berarti penilaian yang dilakukan tersebut konsisten karena kurang dari 0.1, sehingga memperoleh persentase perhitungan dengan nilai Komunikasi 40\%, Kejujuran 34\%, Kerjasama $17 \%$, dan personal 10\%. Hasil penelitian ini menunjukkan bahwa metode AHP dapat digunakan sebagai metode untuk penilaian kompetensi soft skill pegawai Kantor Balai Desa Ambalutu.

Kata kunci: Analytical Hierarchy Process (AHP), Soft Skills, Kantor Balai Desa

\section{PENDAHULUAN}

Penilaian kompetensi soft skill merupakan persoalan yang sangat penting dalam mengelola kinerja pegawai. Sistem yang berjalan di Kantor Balai Desa Ambalutu dalam penilaian pegawai terdapat kelemahan yaitu proses pengolahan datanya belum menggunakan program aplikasi. Sistem penunjang keputusan telah banyak dilakukan, 
Vol. 1 No. 1, Feb 2021, hlm. 89 - 94

DOI: https://doi.org/10.33330/.v1i1.1051

Available online at https://jurnal.stmikroyal.ac.id/index.php/jutsi

penerapan metode sistem pendukung keputusan dalam menentukan pemilihan product terbaik, serta penentuan untuk penerimaan siswa [1],[2].

Terdapat 4 kriteria yang digunakan pada penelitian ini, yaitu komunikasi, kejujuran, kerja sama serta personal. Kriteria tersebut digunakan untuk menilai nilai alternatif. Setelah itu nilai alternatif disusun dalam bentuk matrix untuk mendapatkan nilai rata-rata dari setiap baris.

Rumusan masalah pada penelitian ini adalah bagaimana penerapan decision Sistem dalam penilaian kemampuan karyawan [3],[4]. Serta implementasi metode Analytical Hierarchy Process (AHP). Penelitian ini dapat diterapkan pada Kantor Balai Desa untuk menentukan kemampuan minat dan bakat karyawan. Tujuan pada penelitian ini untuk menerapkan decision support sistem untuk menentukan penilaian kompetensi kemampuan karyawan berdasarkan dari nilai tertinggi.

\section{METODE}

Peralatan utama Analytical Hierarchy Process (AHP) adalah sebuah hirarki fungsional dengan input utamanya persepsi manusia. Dengan adanya hirarki memungkinkan dapat dipecahkannya masalah kompleks atau tidak terstruktur lalu menyusunnya dalam bentuk hirarki. Analytical Hierarchy Process (AHP) memiliki banyak keunggulan dalam proses pengambilan keputusan. Salah satunya adalah dapat digambarkan secara grafis sehingga dapat dipahami oleh semua pihak yang terlibat dalam pengambilan keputusan.

Analytical Hierarchy Process (AHP) akan berjalan menentukan bobot untuk masing-masing kriteria. Kelebihan Analytical Hierarchy Process (AHP) yaitu mengorganisasikan informasi dan memiliki banyak alternatif yang akan dinilai dengan cara membandingkan berpasangan antar alternatif. Kemudian memberikan nilai numerik pada kriteria yang bersifat subjektif. Nilai tersebut akan menentukan suatu kriteria yang akan mempengaruhi dalam penyelesaian dari suatu masalah [5]. berikut ini:

Kemudian mencari nilai konsistensi indeks dengan cara dan rumus seperti

$$
C I=\frac{\lambda m a k s-n}{\mathrm{n}-1}
$$

Keterangan:

$\mathrm{n}$ = banyaknya kriteria

$\mathrm{Cl}=$ Indeks Konsistensi (Consistency Index)

Kemudian menentukan nilai Rasio Consistensi dengan rumus:

Keterangan:

$$
C R=\frac{C I}{\mathrm{IR}}
$$

$\mathrm{CR}=$ Rasio Konsistensi

IR = Indeks Rasio (nilai indeks rasio tergantuk pada jumlah/ukuran matriks) 
Vol. 1 No. 1, Feb 2021, hlm. 89 - 94

DOI: https://doi.org/10.33330/.v1i1.1051

Available online at https://jurnal.stmikroyal.ac.id/index.php/jutsi

Dimana nilai RI atau random index, dapat dilihat di Tabel 1. berikut ini:

Tabel 1. Skala Nilai Random Index

\begin{tabular}{|l|c|c|c|c|c|c|c|c|c|c|}
\hline Ukuran Matriks & 1 & 2 & 3 & 4 & 5 & 6 & 7 & 8 & 9 & 10 \\
\hline Nilai IR & 0 & 0 & 0,58 & 0,9 & 1,12 & 1,24 & 1,32 & 1,41 & 1,45 & 1,49 \\
\hline
\end{tabular}

\section{HASIL DAN PEMBAHASAN}

Analisis proses merupakan kegiatan menguraikan bagaimana melakukan perhitungan data penilaian soft skill menggunakan metode Analytical Hierarchy Process (AHP) untuk menentukan bobot setiap kriteria. Berikut ini langkah-langkah perhitungan dan pemberian bobot kriteria menggunakan metode Analytical Hierarchy Process (AHP):

\section{Penilaian Perbandingan Multi Partisipan}

Berdasarkan hasil pemberian nilai bobot dari kuesioner yang diajukan kepada dua responden maka diperoleh data dan akan di sederhanakan atau dicari rata-rata nilai bobot dari kedua responden dengan cara sebagai berikut:

$$
\frac{X 1 \times X 2}{n}
$$

Keterangan: $X_{1} \quad=$ Nilai bobot koresponden satu

$\mathrm{X}_{2}=$ Nilai bobot keresponden dua

$\mathrm{n} \quad=$ Banyaknya kriteria

Berikut ini merupakan matriks hasil Pemberian Nilai Bobot dari kedua responden yang sudah disederhanakan:

Tabel 2. Matriks Hasil Perataan dari Dua Responden

\begin{tabular}{|c|c|c|c|c|c|}
\hline Kriteria & Komunikasi & kejujuran & kerjasama & Interpersonal & $\begin{array}{c}\text { Priority } \\
\text { Vektor }\end{array}$ \\
\hline Komunikasi & 1,00 & 2,00 & 2,00 & 3,00 & 0,40 \\
\hline Kejujuran & 0,50 & 1,00 & 3,00 & 4,00 & 0,34 \\
\hline Kerjasama & 0,50 & 0,33 & 1,00 & 2,00 & 0,17 \\
\hline Interpersonal & 0,33 & 0,25 & 0,50 & 1,00 & 0,10 \\
\hline Jumlah & 2,33 & 3,58 & 6,50 & 10,00 & 1,00 \\
\hline
\end{tabular}

Dari hasil matriks diatas kemudian dicari perbandingan pada tiap kolom terlebih dahulu untuk memperoleh nilai prioritasnya yaitu dengan cara nilai pada tiap kolom dibagi dengan jumlah kolom tersebut, seperti dibawah ini: 
Vol. 1 No. 1, Feb 2021, hlm. 89 - 94

DOI: https://doi.org/10.33330/.v1i1.1051

Available online at https://jurnal.stmikroyal.ac.id/index.php/jutsi

Kriteria $=\frac{\text { nilai } \text { kolom } \text { kriteria }}{\text { jumlah nilai } \text { kolom kriteria }}$

Komunikasi $=\frac{1}{2,33}=0,429$

Kejujuran $=\frac{2,00}{3,58}=0,558$

Kerjasama $=\frac{2,00}{6,50}=0,308$

Interpersonal $=\frac{3,00}{10,00}=0,300$

Lakukan hal yang sama untuk baris ke-2 dan seterusnya, kemudian didapat matriks nilai perbandingannya pada tabel 3 .

Tabel 3. Nilai Perbandingan Tiap Kolom dibagi Jumlah Kolom

\begin{tabular}{|l|r|r|r|r|}
\hline \multicolumn{1}{|c|}{ Kriteria } & Komunikasi & \multicolumn{1}{c|}{ Kejujuran } & kerjasama & \multicolumn{1}{c|}{ personal } \\
\hline Komunikasi & 0,429 & 0,558 & 0,308 & 0,300 \\
\hline Kejujuran & 0,214 & 0,279 & 0,462 & 0,400 \\
\hline Kerjasama & 0,214 & 0,093 & 0,154 & 0,200 \\
\hline personal & 0,143 & 0,070 & 0,077 & 0,100 \\
\hline Jumlah & 1,000 & 1,000 & 1,000 & 1,000 \\
\hline
\end{tabular}

Tabel 4. Perangkingan Penilaian Kriteria Kompetensi Pegawai

\begin{tabular}{|c|l|c|c|c|}
\hline No & \multicolumn{1}{|c|}{ Nama Kriteria } & Priority Vektor & Persentase (\%) & Rangking \\
\hline 1. & Komunikasi & 0,40 & $40 \%$ & 1 \\
\hline 2. & Kejujuran & 0,34 & $34 \%$ & 2 \\
\hline 3. & Kerjasama & 0,17 & $17 \%$ & 3 \\
\hline 4. & Interpersonal & 0,10 & $10 \%$ & 4 \\
\hline
\end{tabular}

Dari hasil Pemberian Nilai Bobot diatas menunjukkan bahwa pembobotan pada setiap kriteria tersebut konsisten dan dapat digunakan sebagai dasar penilaian kompetensi soft skill pegawai guna meningkatkan kinerja pegawai. Dan hasil tersebut menunjukkan bahwa kriteria komunikasi merupakan kriteria yang paling penting dalam kompetensi soft skill menjadi prioritas ke-1 dengan nilai bobot $40 \%$, berikutnya kejujuran menjadi prioritas ke-2 dengan nilai bobot 34\%, kemudian kerjasama menjadi prioritas ke-3 dengan nilai bobot $17 \%$, dan yang terakhir komunikasi merupakan prioritas ke-4 dengan nilai bobot $10 \%$. Lakukan perhitungan seperti diatas untuk menghitung nilai bobot alternatif. Sehingga diperoleh nilai dan hasil perangkingan untuk alternatif pegawai seperti berikut ini. 
Vol. 1 No. 1, Feb 2021, hlm. 89 - 94

DOI: https://doi.org/10.33330/.v1i1.1051

Available online at https://jurnal.stmikroyal.ac.id/index.php/jutsi

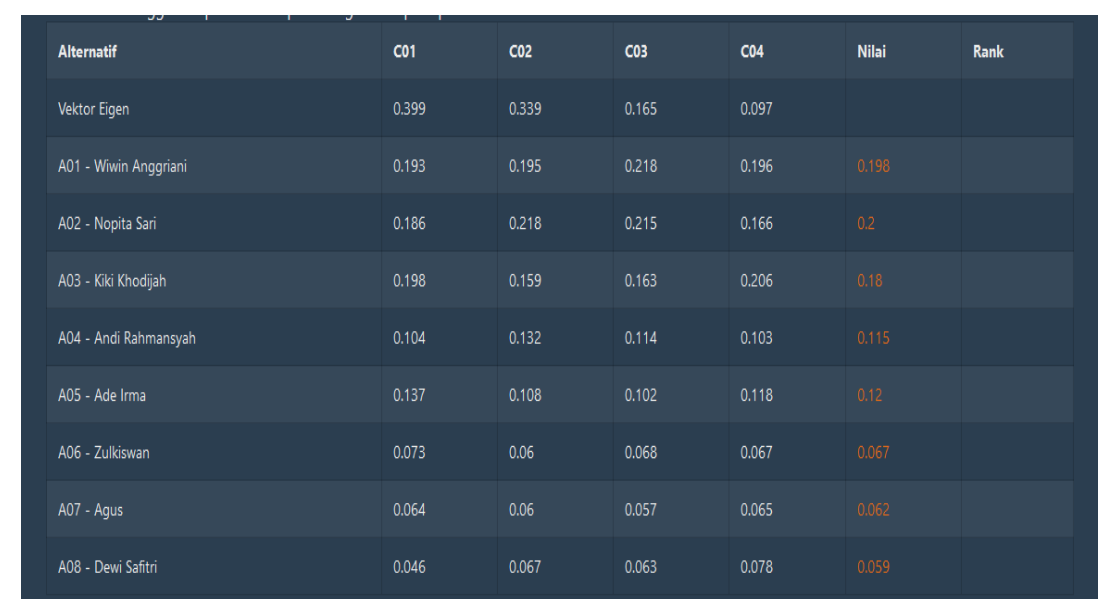

Gambar 1. Form Hasil Perhitungan dan Rangking

Berdasarkan nilai prioritas global dari Tabel 4. maka diperoleh nilai tertinggi kompetensi soft skill pegawai Kantor Balai Desa Ambalutu yaitu atas nama Nopita Sari dengan bobot prioritas 0,200 dan persentase nilai $20 \%$.

\section{SIMPULAN}

Berdasarkan hasil penelitian dan proses penilaian yang dilakukan pada Kantor Balai Desa Ambalutu Kec Buntu Pane mengenai penilaian kompetensi soft skill pegawai dengan 8 (delapan) orang sebagai alternatif, maka dapat diambil beberapa kesimpulan antara lain: Kriteria yang diberikan oleh peneliti sangat berpengaruh sebagai dasar penilaian kompetensi soft skill pegawai. Hal ini dapat dibuktikan dari hasil perhitungan yang dilakukan oleh peneliti yaitu untuk kriteria komunikasi memiliki presentase $40 \%$, kriteria kejujuran memiliki presentase $34 \%$, kriteria kerjasama memiliki presentase $17 \%$, dan kriteria interpersonal memiliki presentase $10 \%$.

Hasil dari penelitian ini dapat membantu Kepala Desa dalam melakukan penilaian kompetensi soft skill pegawai secara cepat dan efisien dengan hasil penilaian yang konsisten. Dari beberapa kriteria yang dipilih sebagai dasar penilaian kompetensi soft skill pegawai maka diperoleh hasil perhitungan untuk 8 (delapan) pegawai sebagai alternatif yaitu dengan kode A02 (Nopita Sari) dengan nilai 0,200, kode A01 dengan nilai 0,198, kode A03 dengan nilai 0,179, kode A05 dengan nilai 0,120, kode A04 dengan nilai 0,115, kode A06 dengan nilai 0,067, kode A07 dengan nilai 0,062, dan kode A08 dengan nilai 0,059. Metode Analytical Hierarchy Process (AHP) merupakan salah satu metode sistem pendukung keputusan yang cocok digunakan untuk proses pengambilan keputusan didalam sebuah penilain, baik penilaian kompetensi soft skill pegawai atau penilaian lainnya. Metode ini juga memudahkan dalam penilaian dengan variabel yang cukup banyak karna waktu yang digunakan dalam proses penilaian cukup cepat dan efisien. 
Vol. 1 No. 1, Feb 2021, hlm. 89 - 94

DOI: https://doi.org/10.33330/.v1i1.1051

Available online at https://jurnal.stmikroyal.ac.id/index.php/jutsi

\section{DAFTAR PUSTAKA}

[1] D. Anggraeni, R. Rahim, and A. Z. Syah, "Decision Support System For Formula Milk Selection Based On Nutrition Value Using Tahani Model Database Fuzzy Method Decision Support System For Formula Milk Selection Based On Nutrition Value Using Tahani Model Database Fuzzy Method," 2018.

[2] Rizaldi and Anggraeni. D, "SISTEM PENUNJANG KEPUTUSAN PENERIMAAN SISWA BARU DENGAN MENGGUNAKAN METODE LOGIKA FUZZY PADA SEKOLAH MENENGAH TINGKAT ATAS (SMA) NEGERI 1 TANJUNG RAYA AGAM," J. Teknol. dan Sist. Inf., vol. 3, no. 1, pp. 1-10, 2016.

[3] P. S. Skill et al., "PENGARUH SOFT SKILLS DAN KOMITMEN TERHADAP KINERJA," pp. 1-9.

[4] I. Conference, I. Technology, D. Anggraeni, T. Model, and S. U. Car, "DECISION SUPPORT SYSTEM SELECTION USED CAR USING THE FUZZY," vol. 4509, no. 177, pp. 235-242, 2020.

[5] R. Umar, A. Fadlil, and Y. Yuminah, "Sistem Pendukung Keputusan dengan Metode AHP untuk Penilaian Kompetensi Soft Skill Karyawan," Khazanah Inform. J. Ilmu Komput. dan Inform., vol. 4, no. 1, p. 27, 2018, doi: 10.23917/khif.v4i1.5978. 